\title{
KRITIK NOVEL WINTER IN TOKYO MENGGUNAKAN PENDEKATAN SOSIOLOGI SASTRA
}

\author{
Hariyani Fazrin Bako', Novi Amelia Natasha², Fitriani Lubis ${ }^{3}$, Emasta Evayanti \\ Simanjuntak ${ }^{4}$ \\ Universitas Negeri Medan \\ Jurusan Bahasa dan Sastra Indonesia, FBS, Medan \\ ${ }^{1}$ hariyanifazrin@gmail.com, ${ }^{2}$ tasyahutagalung2512@gmail.com, ${ }^{3}$ rianiavandi@gmail.com, 4 \\ evayantiemasta@gmail.com
}

\begin{abstract}
Abstrak
Penelitian ini berjudul Kritik Novel Winter In Tokyo menggunakan Pendekatan Sosiologi Sastra. Novel Winter In Tokyo merupakan salah satu diantara tetralogi novel empat musim karya Ilana Tan yang mengisahkan tentang kisah cinta dua insan di musim dingin kota Tokyo. Tujuan dari penelitian ini ialah agar mengetahui bagaimana nilai-nilai sosiologi sastra yang terdapat pada novel Winter In Tokyo karya Ilana Tan tersebut, bagaimana kondisi sosial dan lingkungan yang digunakan sebagi latar dalam pembuatan novel tersebut. Metode yang digunakan pada penelitian ini ialah metode deskriptif dimana penelitiannya di mulai dengan membaca kemudian mengkaji isi dari novel tersebut dan di analisi dari segi kritik sastra melalui pendekatan sosiologi sastra. Berdasarkan penelitian tersebut, hasil yang dapat di peroleh ialah sebagai negara yang maju, Jepang dengan ibukota Tokyo yang merupakan salah satu kota terbesar di Jepang dengan status sosial dan pusatnya perekonomian, bisnis, kebudayaan, menjadikannya kota dengan sistem urbanisasi yang individualis, lingkungan penduduk yang status sosialnya terbilang tinggi, dan interaksi antar masyarakatnya yang cenderung kurang ramah terlebih kepada orang asing.
\end{abstract}

Kata Kunci : Sastra, Novel, Sosiologi.

\section{PENDAHULUAN}

Sosiologi sastra merupakan pendekatan yang berfokus pada sosialisasi dan interaksi kebermasyarakatan dari suatu karya sastra tersebut. Sosiologi sastra berhubungan dengan aspek aspek kemasyarakatan yang berkaitan dengan karya sastra tersebut. Pembahasan mengenai sosiologi sastra biasanya berhubungan dengan keadaan sebenarnya daripada masyarakat tersebut, latar belakang sosial yang terdapat pada karya sastra tersebut, dan kondisi masyarakat pada karya sastra tersebut baik tersirat maupun tersurat.

Karya sastra merupakan suatu hasil dari imajinasi maupun realitas hidup yang di tuangkan penulis di dalam tulisannya. 
Karya sastra kerap kali menjadi acuan atau kiblat dalam melihat dunia dan sekitar. Dalam karya sastra sering kita temukan pembahasan mengenai latar belakang, sistem sosial, dan hal lainnya yang berkaitan dengan suatu karya sastra tersebut. Jenis karya sastra terbagi atas puisi, prosa dan drama. Novel merupakan cabang dari jenis karya sastra prosa modern atau baru. Menurut Drs. Jakob Sumardjo Novel merupakan salah satu jenis karya sastra tuis yang sangat popular di dunia dan memiliki komunitas yang sangat luas di suatu masyarakat yang mengandung nilai-nilai yang dapat kita kaji berdasarkan beberapa unsur.

Dalam pembahasan mengenai kritik sastra menggunakan pendekatan sosiologi sastra pada novel Winter In Tokyo ini akan di bahas mengenai gambaran keadaan masyarakat yang ada pada karya sastra tersebut.

Novel Winter in Tokyo bercerita tentang seorang gadis bernama Ishida Keiko yang merupakan gadis blasteran Indonesia-Jepang. Yang jatuh cinta pada seorang pemuda Jepang di suatu musim dingin di kota Tokyo. Novel Winter in Tokyo ini merupakan salah satu dari tetralogi empat musim karya penulis Ilana Tan yang cukup populer, terutama di kalangan remaja. Ilana Tan sendiri merupakan salah satu penulis terkenal

dengan berbagai karyanya yang selalu laris manis di pasaran dan telah beberapakali novelnya di angkat menjadi film seperti Sunshine Becomes You, Dan Winter In Tokyo itu sendiri. Tujuan dari dilakukannya penelitian ini ialah untuk melihat bagaimana pendekatan sosiologi sastra yang terdapat pada novel Winter In Tokyo karya Ilana Tan tersebut dari kacamata kritik sastra.

\section{KAJIAN TEORI}

Menurut Waluyo (2002 : 68) karya sastra merupakan suatu karya yang berupa imajinasi kreatif yang dilakukan oleh sastrawan dengan proses yang berbeda dengan yang lain. Karya sastra ini selalu memberikan keindahan tersendiri kepada penikmatnya. Tujuan karya sastra ini memberikan makna serta pesan yang terkandung dalam karya sastra tersebut. Novel merupakan salah satu jenis prosa yang memberikan peran dalam kehidupan yang mengangkat setiap permasalahan, baik sosial, masyarakat dan juga budaya. Menurut Sudjiman (1998 : 53) novel merupakan sebuah rekaan yang menampilkan tokoh dan penampilan tersebut berjaan sesuai peristiwa serta latar yang tersusun.

$\begin{array}{lcr}\text { Pendekatan } & \text { sosiologi } & \text { sastra } \\ \text { mempertimbangkan } & \text { segi } & \text { dalam } \\ \text { kemasyarakatan } & \text { (Damono } & \text { 2003:3). }\end{array}$


Pendekatan

memahami,

mempertimbangkan dan menilai permasalahan yang ada pada teks sastra yang dilakukan dengan menganalisis karya sastra menggunakan pendekatan sosiologi sastra. Sosiologi sastra merupakan kajian sastra yang cukup luas. Menurut Ratna (2009 : 3) mengatakan sosiologi sastra merupakan interdisiplin sosiologi dengan sastra yang memiliki kaitan objek yang sama,yaitu manusia dalam masyarakat.

Menurut Jakob Sumardjo (1979 : 12) sastra merupakan produk dari masyarakat itu sendiri. Sosiologi sastra adalah kajian yang melibatkan masyrakat. Sosiologi sastra menelaah objektif dan ilmiah mengenai manusia didalam masyarakat. Berdasarkan uraian diatas dapat disimpulkan bahwa karya sastra merupakan suatu ide, gagasan dan pemikiran yang dapat ditangkap dan dialami pengarang dalam karya sastra. Berkaitan dengan sosiologi sastra dapat dikaitkan dengan sistem politik,ekonomi, hukukm dan lainnya. Sehinggga sosiologi sastra ini merupakan pendekatan karya sastra yang mempertimbangkan dari setiap seginya.

Menurut Alwi (2006 : 601 ) kritik sastra merupakan tanggapan yang disertai argument baik atau buruk terhadap suatu karya sastra. Kritik bukan diartikan sebagai peruntuh sesuatu, melainkan memperbaiki sesuatu yang tidak sesuai dan akhirnya ada kemajuan. Kritik sastra ada karena terjadinya ketidaksesuaian keadaan yang dihasilkan dari komunikasi karya sastra. Sehingga dapat disimpulkan bahwa kritik sastra merupakan suatu tanggapan terhadap karya sastra yang memiliki hubungan dengan masyarakat yang disertai uraian dan perbandingan antara yang baik dan yang buruk dalam karya sastra. Adanya kritik sastra tersebut akan memberi pengaruh dalam masyarakat.

Menurut Ian Watt (1964: 300) mengatakan bahwa hubungan sastrawan,sastra dan masyarakat dapat dipaparkan sebagai berikut :

\section{a. Konteks Sosial Pengarang}

Sebuah karya sastra akan terus berhubungan dengan sistem sosial yang mencakup sistem nilai yang terdapat dalam masyarakat. Sehingga hubungan masyarakat dan pengarang sangat penting guna membentuk isi dari karya sastra tersebut.

\section{b. Sastra sebagai Cerminan Masyarakat}

Menurut Ian Wan genre sastra mencerminkan sikap kelompok sosial bukan sikap sosial seluruh masyakarat. Sehingga yang dimaksud adalah keadaan masyarakat tidak dapat dijadikan sebagai cerminan masyarakat. Akan tetapi sebuah karya 
sastra dapat dilihat dari pandangan sosial pengarang dalam menilai karya sastra sebagai cerminan masyarakat.

\section{c. Fungsi Sosial Sastra}

Fungsi sastra dapat memperbaiki hal yang tidak sesuai agar lebih terlihat keindahan sastra tersebut.

\section{METODE PENELITIAN}

Metode merupakan suatu alat yang digunakan untuk mengkaji suatu penelitian. Sehingga penelitian yang digunakan harus tepat agar memudahkan dalam proses penelitian (Hasan dan Kuntjaraningrat 1997 : 16). Metode yang digunakan dalam penelitian ini adalah metode deskriptif, dimana metode ini menggunakan prosedur penelitian dengan menghasilkan data berupa tulisan, ucapan, maupun perilaku terhadap sesuatu yang di amati. Dalam hal ini, hasil penelitian di jabarkan melalui kutipan-kutipan kalimat yang terdapat dalam teks novel Winter in Tokyo karya Ilana Tan tersebut. Penelitian ini mengambil Data Primer dan Sekunder. Data Primer berupa rujukan dari novel Winter In Tokyo dan data sekunder berupa jurnal penelitian dan ebook mengenai kritik novel Winter In Tokyo menggunakan pendekatan sosiologi sastra. Penelitian ini menggunakan teknik pengumpulan data studi dokumen yang merupakan penelitian berupa sumber tulis, film dan gambar.

\section{HASIL DAN PEMBAHASAN}

Pendekatan sosiologi sastra terdiri dari berbagai sudut pandang. Menurut Ian Watt dalam essainya yang berjudul Sastra dan Masyarakat (1964:300) ilmu sosiologi sastra tersebut saling berkaitan antara sastrawannya, sastranya, dan masyarakatnya secara keseluruhan yang tergambar dalam lingkungannya.

\section{a. Konteks Sosial Pengarang}

Dalam hal ini, yang akan di amati ialah mengenai bagaimana pengarang dalam menggarap ceritanya, bagaimana hubungan antara mengarang dengan masyarakat secara langsung, dan apakah pengarang mendapat dorongan atau sokongan dari masyarakat yang bersangkutan.

Dalam novel Winter in Tokyo karya Ilana Tan ini dapat kita lihat bahwa penulis sangat detail dalam menceritakan detail peristiwa dan gambaran wilayah serta perilaku masyarakatnya. Sehingga terlihat bahwa pengarang sepertinya telah banyak mengetahui Culture dan kondisi masyarakat dari cerita yang akan di garapnya. Seperti pada kutipan; 
"...Sedangkan ayah dan ibu Keiko awalnya tinggal di Tokyo, lalu tiga tahun lalu mereka pindah ke Kyoto kampung halaman ayahnya, untuk mencari suasana yang lebih tenang. Ayahnya memang tidak pernah terbiasa dengan hiruk piruk kota Tokyo.” (Tan, 2016:23).

Berdasarkan kutipan di atas, kita dapat mengetahui bahwa kota Tokyo merupakan salah satu kota yang padat penduduknya. Tokyo memang merupakan kota terpadat di Jepang karena Tokyo merupakan pusat ekonomi, politik, dan akademis dan pusat bisnis.

\section{b. Sastra Sebagai Cermin Masyarakat}

Pada pembahasan ini, suatu karya sastra akan dlilihat sejauh mana ia dapat mencerminkan suatu keadaan masyarakat, mencerminkan apa yang tergambar pada keadaan masyarakatnya dengan sebaik mungkin dan bagaimana pandangan sosial pengarang tersebut dalam mencerminkan masyarakatnya. Seperti pada kutipan;

“.. Sungguh, kau tidak perlu membawaku ketempat seperti ini," kata Keiko dengan wajah berseri-seri dan tersenyum lebar ketika menyadari Kazuto membawanya ke salah satu restoran terkenal di Tokyo, salah satu restoran kesukaan Keiko. (Tan, 2016:122).

Dan pada kutipan;
"...Arena seluncur es itu masih ramai oleh pengunjung yang ingin merayakan malam natal bersama pasangan dan keluarga.” (Tan, 2016:133)

Berdasarkan kutipan kalimat di atas, dapat kita lihat bahwa kehidupan di Tokyo termasuk pada jajaran kota yang sibuk dan ramai. Mereka yang tinggal disana, sebagian besar memiliki ekonomi yang terbilang cukup bagus dengan status sosial dan gaya hidup yang terbilang tinggi dan bagus.

\section{c. Fungsi Sosial Sastra}

Dalam fungsi sosial ini, akan di lihat sejauh mana nilai sastra ini berkaitan dengan nilai sosialnya. Mengenai suatu interaksi sosial dapat kita lihat pada kutipan;

“...Kenapa tidak meminta maaf? Pikir Keiko dengan hati yang jengkel. Jelasjelas pria itu yang salah karena menyenggolnya, tetapi kenapa diam saja?" (Tan, 2016:131).

Dan juga pada kutipan;

"Tidak," sahut Kazuto langsung mengangkat wajah. Sadar kalau suaranya terdengar agak keras, ia melanjutkan dengan suara yang di usahakan lebih santai, "Bagiku nomor enam juga tidak apa-apa." Ia menoleh ke arah si pelayan sambil menunjukkan menu yang di pegangnya, "Aku pesan nomor enam, lalu nona ini memesan yang nomor tiga." Ia menoleh ke arah Akira dan bertanya, "Dan kau, Akira?"

Setelah menyebutkan pesanannya dan si pelayan pergi meninggalkan mereka,..." (Tan, 2016:220). 
"... Takemiya Shinzo mengangkat bahu "aku memang lebih suka sendiri", katanya "Kudengar tadi kau mampir ke restoranku..."

Berdasarkan tiga kutipan di atas dapat kita lihat bahwa nilai sosial dalam masyarakat kurang di terapkan dengan baik, seperti tidak meminta maaf karena telah menyenggol seseorang terlepas apakah itu tidak di sengaja, atau siapa yang menyenggol siapa. Kemudian, tidak adanya keramahan seorang pelayan kepada pelanggannya, seperti tidak merekomendasikan menu apa yang paling di minati di tempat makan mereka, atau bahkan tidak mengucapkan basa basi seperti memastikan ulang pesanan pelanggan atau kata kata lainnya seperti meminta mereka menunggu sebentar dan sebagainya. Juga, pada kutipan ketiga dimana pamannya Kazuto menyatakan dengan gamblang bahwa ia lebih meyukai hidup sendiri. Sifat individualitas sepertinya lebih dominan dalam masyarakat ini, dan kurangnya interaksi sosial antara masyarakatnya terlebih orang asing yang baru di temui.

\section{SIMPULAN}

Berdasarkan hasil penelitian yang dilakukan terkait kritik sastra melalui pendekatan sosiologi sastra pada novel
Winter in Tokyo karya Ilana Tan ini dapat di simpulkan bahwa gambaran kehidupan masyarakat Jepang cukup tergambar detail di dalam novel ini, dimana mereka hidup dalam strata sosial yang cukup tinggi di ibu kota yang sangat padat penduduk, dimana pusat politik, ekonomi, bisnis dan sebagainya tumbuh. Masyarakat yang hidup disana juga cenderung individualis dan kurang menerapkan nilai sosial dalam bermasyarakat.

\section{SARAN}

Berdasarkan kesimpulan dan hasil dari penelitian yang telah dilakukan, beberapa saran yang dapat sampaikan yaitu; Kepada peneliti yang ingin melakukan penelitian lanjutan dapat menganalisis lebih jauh mengenai kritik sastra menggunakan pendekatan sosiologi sastra ini, guna menambah wawasan dan pengetahuan pembaca lainnya.

\section{DAFTAR PUSTAKA}

Daldjoeni, N. 1997. Seluk Beluk Masyarakat Kota. Bandung: Alumin. Kota terbit: Bandung.

Endarwara, Suwardi. 2011. Jurnal Metode Penelitian Sosiologi Sastra. Kota terbit: Yogyakarta: Caps.

Ilana Tan. 2016. Winter In Tokyo Edisi Revisi. Kota terbit: Jakarta. 
Juni Ahyar. 2019. Apa Itu Sastra. Kota terbit: Yogyakarta.

Rahmawati Via. 2012. Kritik Sosial Dalam Novel Tuhan, Izinkan Aku Menjadi Pelacur! Karya Muhidin M Dahlan (Sebuah Tinjauan Sosiologi Sastra). Kota terbit: Jawa tengah.

Redyanto Noor. 2019. Fungsi SosialKultural Sastra: Memajukan Kebudayaan dan Mengembangkan Peradaban. Kota Terbit: Jawa Tengah. 